\title{
CHARLES F. RICHTER: A PERSONAL TRIBUTE*
}

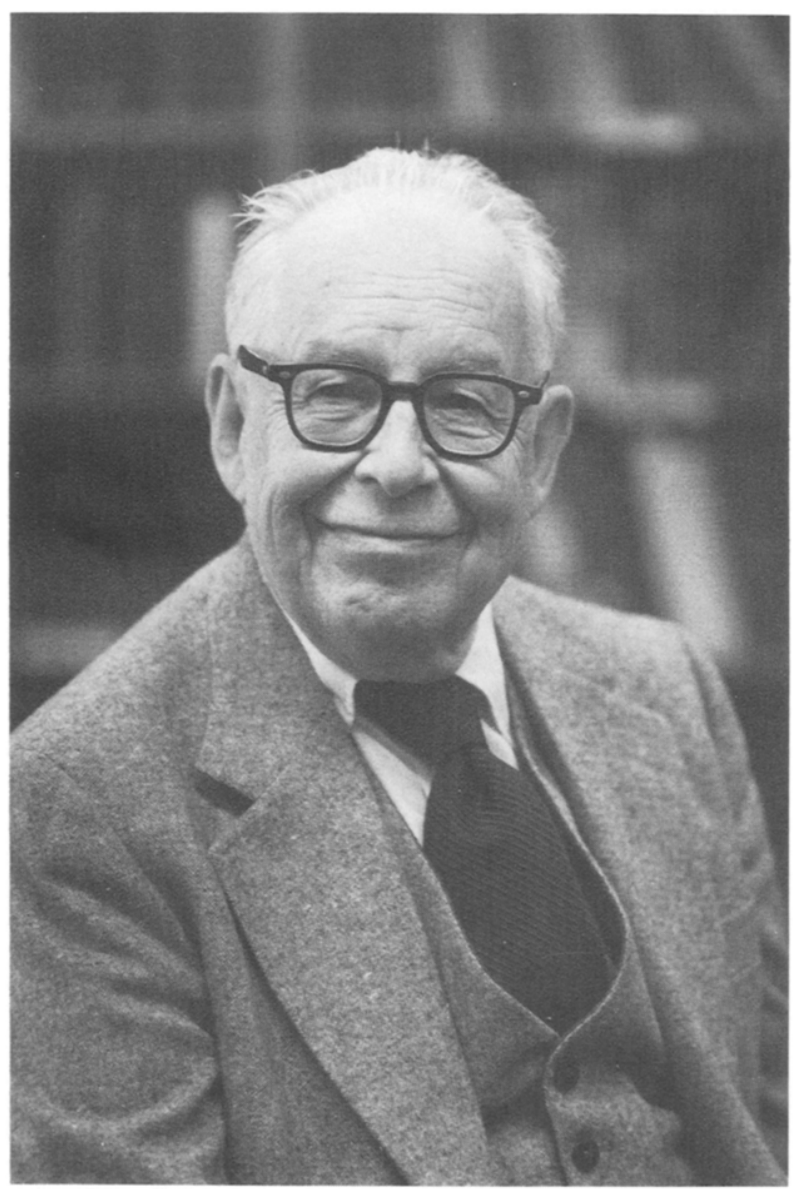

CHARLES F. RICHTER (1900-1985)

With the death of Charles Richter in 1985, the seismological community lost a renowned colleague, and many of us lost a close friend and advisor. Charles was born on a farm in Ohio in 1900, received his A.B. from Stanford in 1920, and his Ph.D. from Caltech in 1928. Virtually his entire professional career was spent at the Seismological Laboratory in Pasadena, first as an employee of the Carnegie Institution of Washington and later as a Caltech faculty member. Following his retirement from Caltech in 1970, he was active for several years in the consulting firm of Lindvall, Richter, and Associates. His wife, Lillian, died in 1972, and they had no children. Richter served as President of the Seismological Society of America from 1959 to 1960 and was the second recipient of its medal in 1977.

Meeting Charles Richter was an experience never to be forgotten, for he was a very unusual person-a man of many contrasts. He could be charming or irascible;

* Adapted from remarks made at the annual luncheon of the Seismological Society of America, Charleston, South Carolina, 24 April 1986. 
he could be outgoing or shy; he could be gentle and warm or abrupt and cold; and he was a man with a truly remarkable memory but, at the same time, was renownedly absentminded. In at least two areas, however, he never wavered in his consistency: he was absolutely dedicated to his science, almost to the exclusion of everything else, and he demonstrated utter intellectual honesty. Charles made no pretense of being a diplomat or a politician, and in things scientific, he said what he meant bluntly and precisely - whether it was with regard to earthquake prediction, the safety of high-rise buildings, or the mental competency of selected newspaper reporters! One did not always have to agree with Charles, but certainly one had to respect his opinions.

Most of the members of our Society will be fully as familiar with Charles' scientific accomplishments as myself. Certainly he is best known, both professionally and publicly, for his introduction of the word "magnitude" into seismological terminology, for his development of the local magnitude scale, and for his subsequent collaboration with Beno Gutenberg in extending the concept to teleseisms. There can be no question of the importance and significance of this work to our science. But, in my opinion, Charles' greatest contribution to science is his 1958 book Elementary Seismology. It is sometimes thought of as a textbook, but it is far more than that; it is a truly remarkable compendium of almost everything seismological, with a strong emphasis on field aspects of the science. Is there a seismologist in the world who does not have this book on his or her shelf? And is there anyone among us who does not refer to it occasionally, despite its present 30-year age?

On a more personal note, let me recall two very pleasant experiences I had with Charles. When the first galley proofs for Elementary Seismology were received from the publisher, Charles was in somewhat of a quandary as how best to check these. Like most authors at this final stage of gestation, the last thing he wanted to do was to read the text still once again. Recognizing that I would want to read the book anyway, I volunteered to read the proofs orally back to Charles. And this turned out to be not only a rewarding educational experience, but also a very pleasant one as well, partly because there is a great deal more humor in the book than many people might assume. Read the footnotes carefully! It was simply a lot of fun to go through these incidents and stories together with Charles, for he had a remarkable sense of humor when he wanted to. For example, in his discussion of the importance of accurate timing in seismology, he relates on page 28 the story of the jeweler who set his chronometer by the noon cannon-firing at the nearby army post. And there is the account of botanical evidence of faulting on page 82 , or, in his discussion of earthquake intensity scales, his colorful quotation on page 145 from the Townley catalog of California earthquakes.

A second very pleasant experience - for both of us, I think - was a field expedition to Baja California, Mexico, in 1956, following a magnitude 6.8 earthquake in the mountains east of Ensenada. We wanted to record aftershocks in a remote area south of the epicenter, so Charles and I set out with our portable gasoline generators and strip-chart recorders, arriving at nightfall at the end of a long dirt road. Now Charles may have been a genius in many ways, but he was anything but a mechanical genius, and after several bright blue flashes in his attempts to get various wires connected, I convinced him to start cooking dinner instead. But the most memorable part of the experience was that, after dinner, the very poor farmer who lived nearby wandered over, and he and Charles got into a lively discussion (in Spanish) that went on well into the night. Charles did not normally communicate with people easily, least of all strangers, but somehow he and this exceedingly poor and simple 
farmer really hit it off. For several years thereafter, when I would visit this area in connection with ongoing geological field studies, our friend Manuel would inquire as to how his friend, "the professor" was doing. And, similarly, Charles would occasionally ask me if I had kept track of his friend, Manuel.

Charles could be absolutely charming when he wanted to be, but he did not always want to be, and many of us have fallen under his wrath at times. Often, of course, his ire at our bumbling was well justified, but at other times we were left troubled and confused as to what had triggered a particular unhappy episode. Charles was a very unpredictable person, and it was not always easy to judge what kinds of things would intrigue him, and what kinds of things would inflame him. Despite his great sense of humor, Charles apparently thought on occasion that he was being made fun of, or that his science was being made fun of; he was an unusually sensitive man in this regard. But I cannot allow those incidents to dominate my memory of the man as one to whom I personally owe a great deal-both for an important part of my education and for some very pleasant and rewarding personal experiences.

Shortly after Charles' death, I received a letter from one of his long-term associates who had experienced, I am sure, many frustrating as well as rewarding interactions with Charles over the years. He ended his letter with the statement, "You know, I sort of loved the man." I could not have said it better myself.

Charles' place in seismological history is probably best summarized in a letter I received from Tom Hanks, one of his former students and colleagues:

"It is perhaps worth noting that Richter's passing pretty much marks the passing of the "charter members" of earthquake seismology. I realize that there were seismology and seismologists-even earthquakes!-before Charles and his colleagues, but the small group of people active in the 1920's and 1930's gets the credit, I think, for putting seismology on the map as a real scientific discipline. Fieldworthy (as opposed to laboratory) instruments, regional networks, earthquake catalogues, magnitude scales, earthquake statistics, seismological studies of the crust, mantle, and core all have their origins in these days, at least insofar as a systematic approach is concerned. This group is all gone now, or mostly so, depending on who counts whom as a member of that early club. In any event, we're on our own from here on in. We're well prepared for this, I think, thanks in large part to Charles and his colleagues."

\section{SELected Bibliography of Charles F. Richter}

Richter, C. F. (1927). The hydrogen atom with a spinning electron in wave mechanics, Proc. Natl. Acad. Sci. 13, 476-479.

Wood, H. O. and C. F. Richter (1931). A study of blasting recorded in southern California, Bull. Seism. Soc. Am. 21, 28-46.

Gutenberg, B. and C. F. Richter (1934). On seismic waves (first paper), Gerl. Beitr. zur Geophysik 43, 56-133.

Gutenberg, B. and C. F. Richter (1935). On seismic waves (second paper), Gerl. Beitr. zur Geophysik 45, 180-360.

Richter, C. F. (1935). An instrumental magnitude scale, Bull. Seism. Soc. Am. 25, 1-32.

Gutenberg, B. and C. F. Richter (1936). On seismic waves (third paper), Gerl. Beitr. zur Geophysik 47, $73-131$.

Gutenberg, B. and C. F. Richter (1936). Materials for the study of deep-focus earthquakes, Bull. Seism. Soc. Am. 26, 341-390.

Gutenberg, B. and C. F. Richter (1939). On seismic waves (fourth paper), Gerl. Beitr. zur Geophysik 54, 94-136.

Richter, C. F. (1943). Mathematical questions in seismology, Bull. Seism. Soc. Am. 49, 477-493.

Gutenberg, B. and C. F. Richter (1949). Seismicity of the Earth, Princeton University Press, Princeton, $273 \mathrm{pp}$ (second rev. ed., 1954). 
Richter, C. F. and J. M. Nordquist (1951). Instrumental study of the Manix earthquakes, Bull. Seism. Soc. Am. 41, 347-388.

Richter, C. F. (1955). Foreshocks and aftershocks [of the 1952 Kern County earthquake], Calif. Div. Mines Bull. 171, 177-197.

Gutenberg, B. and C. F. Richter (1956). Magnitude and energy of earthquakes, Ann. Geofis. 9, 1-15.

Richter, C. F. (1958). New dimensions in seismology, Science 128, 175-182.

Richter, C. F. (1958). Elementary Seismology, W. H. Freeman and Co., San Francisco, California, 768 pp.

Richter, C. F., C. R. Allen, and J. M. Nordquist (1958). The Desert Hot Springs earthquakes and their tectonic environment, Bull. Seism. Soc. Am. 48, 315-337.

Richter, C. F. (1959). Seismic regionalization, Bull. Seism. Soc. Am. 49, 123-162.

Allen, C. R., P. St. Amand, C. F. Richter, and J. M. Nordquist (1965). Relationship between seismicity and geologic structure in the southern California region, Bull. Seism. Soc. Am. 55, 753-797.

Richter, C. F. (1969). Transversely aligned seismicity and concealed structures, Science 166, $173-178$.

Richter, C. F. (1971). Sporadic and continuous seismicity of faults and regions, Roy. Soc. New Zealand Bull. 9, 171-173.

\section{SEISMOLOGICAL LABORATORY}

Clarence R. Allen

California INSTITUTE OF TEChNOLOGY

Pasadena, California 91125

(Division of Geological and Planetary Sciences Contribution No. 4511) 